\title{
A Municipal Right to Vote
}

BY USMAN AHMED, DAVID MOON, AND ROB RICHIE

Since the U.S. Constitution was ratified, the United States has moved closer to a system of equality in which all people have the right to vote regardless of sex, race, ethnicity, or location. Although there are still serious problems in today's voting system, there have been significant advances over the last two centuries to help transform the voting population from white male landowners of at least twenty-one years of age to an electorate in which almost all citizens who are at least eighteen can vote freely. But this process has been carried out piecemeal over a course of decades and never been all-encompassing. It is time to carry forward the evolution of our voting rights at a city level in a manner that builds support for what ultimately is needed: a constitutional amendment guaranteeing all citizens an affirmative right to vote.

Municipal reform is often overlooked, but it can be one of the most efficient and potent methods of fostering political change. The Municipal Right to Vote Initiative seeks to have cities call for a constitutional right to vote and to pledge to enact ordinances and charter changes in the spirit of that proposed amendment, thereby building both political support for an amendment and showcasing what it would mean for protecting and expanding suffrage. A unique approach to voting rights, this municipal initiative is grounded in the fact that municipalities have the ability to protect and expand voting rights beyond their protections in the U.S. or state constitutions and law.

The United States currently administers federal, state, and local elections through a decentralized patchwork of regulations, with local election officials holding great discretion over important decisions such as who gets to vote, polling hours, ballot design, voting equipment purchases, machine alloca-

(C) 2008 Wiley Periodicals, Inc

Published online in Wiley InterScience (www.interscience.wiley.com) tion, and selection of polling locations. Indeed, it is estimated that more than thirteen thousand counties and cities make independent decisions about administration of elections for our highest office, directly affecting how many people vote and how many of their votes are accurately recorded. States also have wide leeway in granting or removing suffrage rights-for example, on the basis of whether a citizen has a felony conviction, or whether one is a citizen or of a certain age. Citizens living in American territories such as Puerto Rico, Guam, America Samoa, and the Virgin Islands have no power to vote for president, while citizens in Washington, D.C., share with them a lack of representation in the U.S. Congress. In all, more than nine million American citizens could vote for representatives in Congress if they lived in a different state.

Thanks to the combination of a lack of political will at the federal level to implement broad public interest standards and harmful judicial precedents such as the 2000 Bush v. Gore decision, which stated that individuals do not have a constitutionally protected right to vote in presidential elections, voters in different states and even counties or cities can have their votes for the same office counted differently, and sometimes not at all.

Theoretically, our right to vote can be weakened or even stripped at any time by the state and federal governments, but it is our civic duty to make sure that any injustice does not occur in elections controlled by our own communities. With this new municipal right to vote initiative, we hope to make possible at the local level what many think is not currently possible at the federal and state levels. Expanding voting rights and effecting electoral reform in cities can more efficiently and effectively instill the goals of the program. Municipalities have 
A unique approach to voting rights, this municipal initiative is grounded in the fact that municipalities have the ability to protect and expand voting rights beyond their protections in the U.S. or state constitutions and law.

far less bureaucracy than the federal government, and many are willing to enact groundbreaking reforms.

Our initiative will also build momentum for a universal right to vote protected in the U.S. Constitution. A proposed constitutional voting rights amendment, introduced in recent Congresses by Rep. Jesse Jackson Jr. (D-Ill.) as HJR 28, has earned more than sixty sponsors, including every member of the Congressional Black Caucus in the 2005-06 session, but will need deeper grounding in a grassroots movement to succeed. Cities can lead a growing chorus of voices calling for a constitutional right to vote, while at the same time implementing the ideals of the right to vote amendment in their municipalities in a way that brings immediate positive changes for voting rights.

Ours is a flexible concept that gives localities the option of implementing reforms as a package or in pieces, depending on what is possible. In an ideal version, cities would add affirmative rights to vote to their city charter, to grant all citizens a protected right to vote in city elections while passing a resolution in support of a federal right to vote amendment and ongoing review of how suffrage is protected in the community. If enough cities pass resolutions while simultaneously making tangible reforms for city elections, a critical mass of attention could be generated to highlight the larger problems of our decentralized election systems.

The Municipal Right to Vote package would generally feature a call for a constitutional right to vote and for the community's commitment to ongoing review of laws and practices that might better expand and protect voting rights and inspire voter participation. It would include seven specific reforms affecting suffrage in cities.

\section{Uniform Standards and Ballots, and Real Accounta- bility}

We need uniform standards for ballot design, poll worker training, polling place locations, and ballot access for presidential candidates. We need ongoing funding for elections and rigorous evaluation of what works and what can be improved.

The average poll worker is seventy-two, and they usually make around minimum wage. The ballots are oftentimes more confusing than they ought to be. Poll workers are usually given one day of training and then asked to deal with myriad problems that arise on Election Day. These issues must be handled with a standard method for poll worker training, pay, and qualifications. Ballots must be simplified, and methods for confirmation of votes must be implemented. A city charter could stipulate many of these provisions for municipal elections.

\section{Universal Voter Registration}

We need full and accurate voter rolls, which is the international norm. Every citizen approaching age eighteen and every person becoming a citizen should be automatically registered by the time he or she is eligible to vote as part of a change from an "opt in" approach to registration to an "opt out" one where the government and individual share a mutual responsibility for voter registration.

As in many political process issues, the United States has fallen behind the rest of the world when it comes to voter rolls. It is obviously an individual's right to choose whether he or she votes on Election Day, but being unable to vote owing to overlooking an opportunity to register or being left off the rolls is deplorable. FairVote proposes several improvements: increased motor voter and high school registration 
and, at the least, meeting the requirements set forth in the Help America Vote Act. All of these methods are described in detail under the 100 percent Registration Project found at FairVote.org, and many can be adopted at the municipal level. If need be, municipalities can indeed maintain their own rolls to supplement ones maintained by the county and state.

\section{Accessibility: Early Voting, Election Holiday, More Polling Stations}

Early voting, no-excuse absentee voting, and an Election Day holiday would make voting more convenient and potentially increase participation in the democratic process. More polling places and polling states as well as longer polling hours are also a sensible investment in protecting the right to vote. In some combination, these reforms would also help shorten the absurdly long lines seen in the 2004 election.

Several nations around the world have election holidays, allowing voters to take their time rather than rushing to the polls on lunch break. The incredibly long lines toward the end of the day are also a large problem that causes thousands of voters to be disenfranchised. Early voting, an election holiday, and longer polling hours would allow more individuals to come to the polls at their leisure, and if effectively administered they would also give poll workers a more stress-free environment. Cities at least could ensure that municipal employees have Election Day holidays for city elections and avoid short polling hours-such as the four-hour polling day one Maryland locality had until recently for its elections.

\section{Fair Provisional Ballot and Voter ID Laws}

As evidenced particularly clearly in the elections of 2004, lack of fair and consistent federal requirements regarding provisional ballots and voter identification laws can lead to confusion, inequity, and lost votes. This can be addressed directly by the municipal right to vote movement. The lack of universal standards has led to a large amount of confusion as states and municipalities seek to use the best possible methods for a smooth election. Varying ballots and unfair use of voter ID laws have confused and disenfranchised tens of thousands of voters. For example, millions of Americans do not have a government-issued photo ID. A city could potentially allow voters to vote in municipal elections with sensible protections that do not include requiring a photo ID, even where the state requires it for state and federal elections.

\section{Public Interest Voting Machines}

We should use our nation's great technical expertise and resources to create voting equipment that supports public interest needs, addresses accessibility needs of the disabled community, has open-source software, is ready to run ranked choice voting methods such as instant runoff voting, and includes a voter-verifiable paper ballot that can be adapted for all localities' election methods.

Voter verifiable paper ballots are critical to the efficiency and accuracy of an election. Recent elections have proved how important it is to be able to verify each and every vote. Electronic voting systems without an audit trail are always going to be controversial. Voting machines must be adapted to various localities and be able to address those with special needs. When making purchasing decisions and other equipment choices, cities can often opt to use paper ballots or require their equipment vendors to furnish flexible, public interest equipment. Where cities lack that power, they can petition the county or state making the purchases to do so.

\section{Voting Rights for More Americans}

More than nine million American citizens are denied the same right to vote that they would enjoy if living in another part of the country. Several states deny voting rights for life to anyone once convicted of a felony. All states currently deny voting rights to legal immigrants, but a handful of localities allow these new Americans to vote.

Disparate felon voting rights are prime examples of a lack of universal standards. Each state handles this 
matter in its own way, disenfranchising millions of Americans. People with felony convictions are granted most of their basic citizenship rights once they leave prison, but many are never allowed to vote again, underscoring that voting is not a guaranteed right for every American in the same way that constitutionally protected rights such as free speech and freedom of assembly are protected. Cities, even where the state has disenfranchised people with felony convictions, may be able to allow these citizens to vote in municipal elections.

\section{Nonpartisan Election Administration}

To guarantee the integrity of the voting process, partisan officials should not make decisions about administration-at the very least not without full accountability and transparency for their decisions. The role of election official should be esteemed and regarded as one of enormous importance. In most states, an elected secretary of state has important powers over how elections are administered, and county election directors are elected in several states. Most election officials are law-abiding and execute laws to the best of their ability. Yet without standards or requirements in place that are based on transparency and accountability, there is no guarantee all election administrators will act in this manner. Cities can take the lead in ensuring that their election officials act in an unbiased and nonpartisan manner. They also should allow nonpartisan observers full access to the electoral process.

\section{HAVA: A Good First Step, but More Is Needed}

The federal Help America Vote Act (HAVA) was passed in 2002 in response to the voting discrepancies exposed in the 2000 presidential election. HAVA imposes a number of requirements on states, with the stated purpose of bringing voting practices in the separate states and precincts to a national standard. It also allocated federal funds to states for election administration for the first time in our history, again showing how much protection of voting rights is seen not as a federal right but as a state and local one.
Key provisions of HAVA:

- HAVA requires that all states upgrade their voting systems. Many precincts in 2000 were still using lever and punch card voting systems. The new legislation mandates that these machines be replaced with upgraded voting machines immediately and sets aside federal funding for that purpose.

- All precincts are required to upgrade to include electronic voting devices. HAVA critics are concerned about this statement, believing that electronic voting machines were part of the problem in 2000 and an even bigger problem in subsequent elections. Yet old punch cards and lever machines clearly failed millions of voters as well.

- HAVA sets in place several national requirements pertaining to voter registration. First, all citizens must present either a valid driver's license or the last four digits of their social security number when registering to vote in a federal election. Second, all voters must present a valid driver's license, the last four digits of their social security number, a valid photo ID, or a copy of a current utility bill, bank statement, government check, paycheck, or other government document that shows the name and address of the voter either with the registration or when he or she votes.

- HAVA contains clauses mandating enforcement of its provisions. The federal attorney general has the right to bring civil action against any state or locale as he or she deems necessary for enforcement of the uniform and nondiscriminatory requirements of the law. In addition, any state receiving any of the federal funding allocated by the bill must establish an administrative complaint process for citizens to file their complaints. The state must review all complaints but can dismiss a complaint that is felt to be unfounded.

Notably, HAVA does not cover municipal elections. This is not just a theoretical concern; many cities hold their elections separately from federal and state elections-on the one hand creating real opportunities for weakening of the right vote, but on the other allowing cities to go further than states in protecting 
voting rights. As a result, a key centerpiece to any municipal right to vote campaign could be to pass a charter amendment or ordinance extending HAVA requirements to city elections, and then building on those HAVA requirements.

\section{Getting Involved: Four Methods of Municipal Reform}

We suggest four methods for groups and individuals to get involved in local election reform efforts.

\section{Draft Resolutions}

Draft resolutions allow organization of local member groups to aid in the pursuit of major goals such as the call for a constitutional right to vote and a rigorous review of suffrage rights in one's community. A draft resolution can come in many forms, but it should be designed to show public support for a reform; we have an example on our Website. First, one could use a draft resolution for a religious or community organization. These can be passed out in churches and various other local gatherings to garner support for a reform that is clear and concise. Second, one could propose production of a draft resolution by a secular or government organization. Finally, one could propose a draft resolution that will be adopted directly by the city council.

\section{Task Force}

A task force is a legislative commission approved by government authority to conduct studies on particular subjects. Task forces can be powerful tools when used properly. Citizens can lobby the local government to assign a task force to study the issues of voting rights in their municipality, particularly limitations in how the municipality protects the right to vote.

\section{City Charter Review}

Instituting reforms in city charters is the most lasting approach to reform. Reviews are public forums held periodically wherein reforms to the charter can be proposed and implemented. A city charter review is the most common method of municipal reform. The charter commission meetings are open to any suggestion from any resident. There are usually fewer than fifteen members who sit on the commission, and if a majority of them agree with the ideals of the right to vote, change can be enacted rather quickly.

\section{Initiatives to Amend the Charter}

This activist-based approach to reforms may be limited by city charter provision, but it could be a powerful tool in the Right to Vote movement. It circumvents current elected officials. By garnering a certain number of signatures, dependent on the city charter and usually a percentage of the total population, and winning at the ballot box, voting rights can be protected in new law. The amendment will be added to the charter or statutes, so it is best if it is written in charter language, ideally with full involvement of stakeholders in the community.

\section{A Time for Action}

The Right to Vote Initiative is a long-term project that will require years of diligent work from thousands of activists around the country. The ultimate fix would be an amendment to the U.S. Constitution guaranteeing all citizens the right to vote, but even such an amendment only gives grounding for citizens and government to better protect our suffrage. Cities hold a great deal of power, and if several begin to enact the reforms of the Municipal Right to Vote Initiative it will create a new climate for the federal government to follow suit and model how best to honor, respect, and use the right to vote. In the coming years, FairVote plans to commit significant time and resources to this project, partnering with local volunteers, organizations, and elected officials motivated by the vision of a universal right to votebringing millions of people into an improved voting process.

Usman Abmed is a law student at the University of Michigan. David Moon is FairVote's program director and Rob Richie is its executive director. 